\title{
SPATIAL VARIABILITY OF RUBBER TREE DENDROMETRICS CHARACTERISTICS AND SOIL PHYSICAL ATTRIBUTES
}

\author{
Glécio Machado Siqueira ${ }^{1,}$; Sidney Rosa Vieira²; Luiza Honora Pierre²; Célia Regina Grego \\ ${ }^{3}$ Federal University of Maranhão, UFMA - Geosciences Department. São Luís/MA, Brazil. ${ }^{2}$ Agronomic Institute, IAC - \\ Campinas/SP, Brazil. ${ }^{3}$ Brazilian Agricultural Research Corporation, EMBRAPA - Campinas/SP, Brazil. \\ ${ }^{*}$ Corresponding author: gleciosiqueira@hotmail.com
}

Received: Dec. 12, 2017 - Accepted: Aug. 16, 2017

http://dx.doi.org/10.22615/2526-1746-jgm-2.2-7856

\begin{abstract}
The objective of this study was to determine the spatial variability of rubber tree dendrometrics characteristics (diameter and height) and its relationship with soil physical attributes (soil penetration resistance and hydraulic conductivity). The experiment was located in Campinas, State of São Paulo, Brazil in a experimental station of the Instituto Agronômico, in a 10 ha area with rubber trees grown since 1992. Samples were taken from 232 points in a grid of $20 \times 20 \mathrm{~m}$. The average diameter at the chest height and the height of the trees were determined using the average of four plants. The following soil physical attributes were studied: soil resistance to penetration up to $0.40 \mathrm{~m}$ deep and water infiltration in two depths (0-0.10 $\mathrm{m}$ and 0.10-0.20 m). All plant and soil variables showed moderate to weak spatial dependence among samples. There was also correlation between spatial variability maps of the rubber tree dendrometric characteristics and the soil physical attributes studied.
\end{abstract}

Key words: geostatistics, plant and soil attributes, Hevea brasiliensis.

\section{VARIABILIDADE ESPACIAL DE CARACTERÍSTICAS DENDROMÉTRICAS DE SERINGUEIRA E DE ATRIBUTOS FÍSICOS DO SOLO}

\begin{abstract}
RESUMO: O objetivo deste trabalho foi determinar a variabilidade espacial de características dendrométricas de seringueira (altura e diâmetro das árvores) e sua relação com atributos físicos do solo (resistência do solo à penetração e condutividade hidráulica do solo saturado). O experimento está localizado no Centro Experimental Central do Instituto Agronômico, em uma área de 10 ha cultivada com seringueira desde 1992. As amostragens foram realizadas em 232 pontos com espaçamento regular de $20 \times 20$ m. As características das plantas de seringueira diâmetro médio na altura do peito e a altura foram determinadas utilizando a média de quatro árvores. Os atributos físicos do solo estudados foram, a resistência do solo à penetração até $40 \mathrm{~cm}$ de profundidade e a infiltração de água no solo em duas profundidades (0-0,10 m e 0,1-0,20 m). Todas as variáveis de planta e solo apresentaram dependência espacial moderada a fraca entre as amostras. Também houve correlação entre os mapas de variabilidade espacial das características de plantas de seringueira e dos atributos físicos do solo estudados.
\end{abstract}

Palavras-chave: geoestatística, atributos de planta e solo, Hevea brasiliensis. 


\section{INTRODUCTION}

The rubber tree [Hevea brasiliensis (Willd. ex Adr. To Juss.) Müell. Arg.] is originating from the Amazon region of Brazil, is currently the main source of natural rubber in the world. World production of natural rubber in 2012 was 11.327,00 tons, for a consumption of $11,005,00$ tons, being that $7,390.50$ tons originated in Southeast Asia, including countries such as Thailand (31.00\%), Indonesia (26.61\%), Malaysia (7.63\%), India (8.11\%) and Vietnam (7.60\%) (IRSG, 2013).

According to CARDINAL et al. (2007), Brazil has had a monopoly on world production of natural rubber at the beginning of the twentieth century, and currently has a little expressive production of 100 thousand tonnes, while its consumption reaches 270 thousand tons. Despite having its origin in the Amazon region, currently in Brazil the main crops are located in the Western Plateau State of Sao Paulo, due mainly climatic conditions which do not favors the development of the fungus Microcyclus ulei [(P. Henn. ) V. Arx] (GONÇALVES et al., 2001). Besides the aspects linked to the extraction of latex, other aspects are also helping to boost the rubber tree in Brazil, and with regard to the protection of soil and water (SANTOS and MOTHÉ, 2007), or even as a species able to reposition forest and production of way, contributing in the process of extracting carbon from the atmosphere, thus, reducing the greenhouse gases (SBS, 2006).

A striking feature in areas of plantation forestry is its apparent homogeneity, however, is a frequent observation of height and diameter variations in a forestry area.

KANEGAE JUNIOR et al. (2007), said which the forest stratification is usually done based on cadastral information, such as age, species, the spacing and the system of management, although the best method would be to the stratification based on the variable of interest. In this sense, ROSA FILHO et al. (2009) emphasized that the use of precision forestry improves collection and analysis of geospatial data, allowing interventions located in the forest, with adequate accuracy and precision.

The heterogeneity of forest cultivation may be related to several physical-chemical factors and soil and climatic characteristics of the region. SIQUEIRA et al. (2013) describes that the physical attributes of soil, such as soil resistance to penetration interfere in the development of root plants. Thus, the study of the spatial distribution of the variables dendrometrics parameters of rubber tree plants and its relationship with other soil attributes, it is essential to understand the behavior and the relationship between those properties.

Several studies have shown that the variability of soil properties is spatially dependent, that is, within a certain area, the difference between the values of a particular property can be expressed as a function of the distance of separation between the sampled points. According to VIEIRA et al. (1981), the analysis of samples that do not consider the variances calculated and the distance of separation between samples, does not provide a complete description of the variability of a property.

Thus, geostatistics provides information about the spatial structure of the variables and estimate the unknown values and the values of variables correlated. It should be used to determine the spatial dependence of the properties of soil and the attributes of growth and production of culture. Therefore, 
data that would be analyzed with the statistical difficulty due to the spatial variability of soil have greater ease of analysis with these tools.

The objective of this study was to evaluate the spatial variability and correlation between dendrometrics characteristics from Hevea brasiliensis (diameter and height) and physical attributes of soil (soil penetration resistance and hydraulic conductivity).

\section{MATERIAL AND METHODS}

This study was sited an area of 10 ha of the Centro Experimental Central, belonging to the Instituto Agronômico (IAC), Campinas, São Paulo, Brazil, with latitude $22^{\circ} 53^{\prime} \mathrm{S}$, longitude $47^{\circ} 04^{\prime} \mathrm{W}$, with an average elevation of 600 and slope of $6.5 \%$.

The type of soil of the area is a Rhodic Eutrudox (USDA, 1996) and the Köppen climate classification is the type Cwa.

The trees of Hevea brasiliensis were planted in 1992 using the following clones IAC 35, PR 261, GT 1, PS 235, RRIM 70, IAN 835, PR 255, RRIM 600 and CR 330.

The trees conform to a spacing of $3 \mathrm{~m} \times 7$ $\mathrm{m}$, adding a total of 928 trees. They were demarcated 232 sampling points of a grid of $20 \mathrm{~m} \times 20 \mathrm{~m}$ (Figure 1). Each section contains four trees, called $A, B, C$ and $D$, arranged around the point of sampling.

The dendrometric characteristics evaluated were: diameter of the trees (Diameter, cm) and height of the trees (Height, $\mathrm{m}$ ). The diameter at breast height was measured at $1.3 \mathrm{~m}$ height. The height of the trees was determined with clipboard dendrometric or hipsometer.

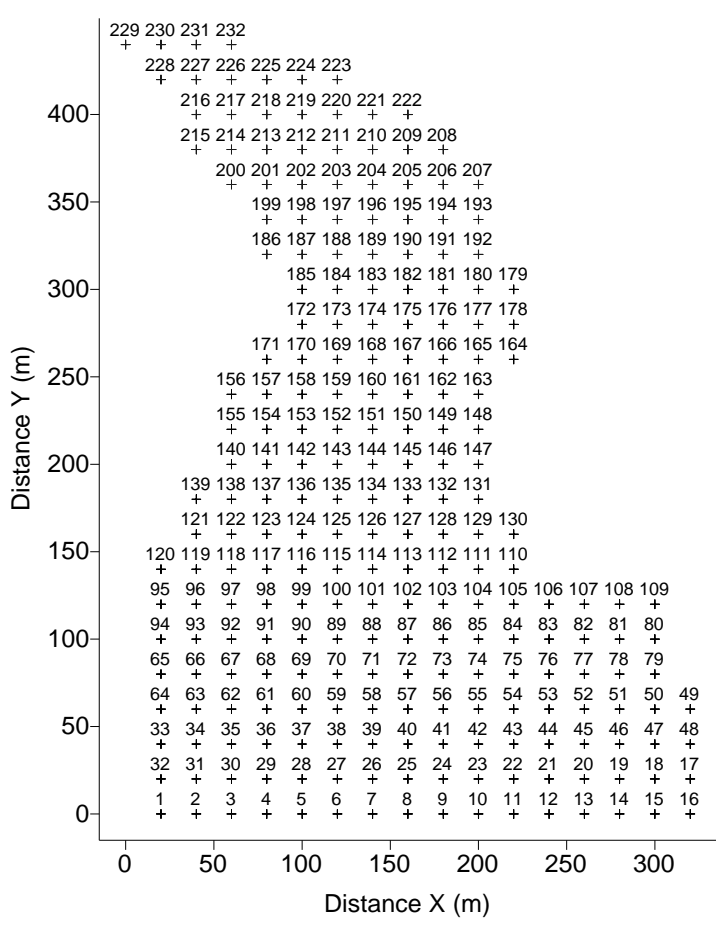

Figure 1. Grid sampling of the dendrometrics characteristics and soil physical attributes.

The physical attributes measured were: soil mechanical resistance to penetration (RP, $\mathrm{MPa}$ ) and the saturated hydraulic conductivity of soil (Cond, $m$ day $^{-1}$ ). The soil resistance to penetration was measured with penetrometer of impact model STOLFPLANALSULCAR (STOLF et al., 1983) to $0.40 \mathrm{~m}$ deep, the soil resistance to penetration calculated for each $0.10 \mathrm{~m}$ depth $\left(\mathrm{RP}_{0-10}, \mathrm{RP}_{10}\right.$ 20, $\mathrm{RP}_{20-30}$ and $\left.\mathrm{RP}_{30-40}\right)$. The hydraulic conductivity of the soil was measured with permeameter of constant load model IAC (Vieira, 1998), the depth $0-10 \mathrm{~m}$ (Condo-10) and 0.1-0.2 $\mathrm{m}$ ( Cond $\left._{10-20}\right)$ with 2 constant head ( 3 and $5 \mathrm{~cm}$ ).

Initially the statistical parameters (mean, variance, standard deviation, coefficient of variation, minimum value, maximum value, skewness, kurtosis) were obtained in order to verify existence of a central tendency and dispersion of the data using the Stat program (Vieira et al., 1983). When a data set approaches the normal distribution, the 
values for skewness and kurtosis coefficients approach zero. These values together with the other classical statistical parameters are useful to evaluate the magnitude of the data dispersion around a central tendency value.

The spatial variability was analyzed using semivariograms obtained with program Avario described in VIEIRA et al. (1983) obtaining the parameters of the models fitted to individual semivariograms (VIEIRA, 2000). Scaled semivariograms were calculated according to Vieira et al. (1997) in order to plot them with the semivariances on the same scale. The semivariogram, $\gamma(h)$, of $n$ spatial observations $z(x i), i=1, n$, can be calculated using Equation (1).

$$
\gamma(h)=\frac{1}{2 N(h)} \sum_{i=1}^{N(h)}\left[Z\left(x_{i}\right)-Z\left(x_{i}+h\right)\right]^{2}
$$

where $N(h)$ is the number of pairs of measured values $Z\left(x_{i}\right), Z\left(x_{i}+h\right)$, separated by a vector $h$, which is the distance determined from the $Z\left(x_{i}\right)$ and $Z\left(x_{i}+h\right)$ coordinates. Calculation of equation (1) generates $\gamma(h)$ values corresponding to $h$ distances, for the construction of the semivariogram. According to VIEIRA (2000), it is expected that measurements located near one another are more similar among themselves than those separated by great distances, i.e., where $\gamma(h)$ increases with the $h$ distance until a maximum value at which it stabilizes, at a level corresponding to the limit distance of spatial dependence, which is the range. Measurements located at greater distances than the range have random distribution and are therefore independent among themselves; beyond this distance, classic statistics can be applied.

Spherical mathematical models were adjusted to the experimental semivariograms, which allowed the visualization of the nature of the spatial variation of the variable. The criteria and procedures for fitting the semivariogram models were made according to VIEIRA et al. (1983). Based on the model used to fit the data, the following semivariogram parameters were defined: a) nugget effect $\left(C_{0}\right)$, which is the g value when $h$ $=0 ; \mathrm{b})$ range of the spatial dependence $(a)$, which is the distance at which $\gamma(h)$ remains approximately constant, after increasing as $h$ increases constant; $c)$ threshold $\left(C_{0}+C_{1}\right)$ which is the $y(h)$ value beyond the range approaching the data variance, if it exists where $N(h)$ is the number of pairs of observations separated by a distance $h$.

The degree of spatial dependence (GD) was calculated using Equation (2).

$$
G D=\left(\frac{C_{0}}{C_{0}+C_{1}}\right) * 100
$$

According to CAMBARDELLA et al. (1994), the GD represent the spatial randomness and can be used to classify the spatial dependence as strong if $\mathrm{GD}<25 \%$, moderate for $\mathrm{GD}$ between $26 \%$ and $75 \%$ and weak with GD > $75 \%$.

Soil moisture contents that showed that the semivariance depended on distance were interpolated, without bias and with minimum variance using the kriging system (VIEIRA, 2000).

\section{RESULTS AND DISCUSSION}

The Table 1 shows the descriptive statistics of dendrometric and physical parameters measured. The dendrometric characteristics of Hevea brasiliensis showed low values of coefficient of variation (CV), while the physical attributes showed higher values of CV mainly 
data from soil saturated hydraulic conductivity, as proposed classification by WARRICK and NIELSEN (1980). The values of CV for the saturated hydraulic conductivity and soil mechanical resistance to penetration to coincide with the values found by VIEIRA (1998) and SOUZA et al. (2004), respectively.

Table 1. Statistical parameters dendrometrics characteristics and soil physical attributes.

\begin{tabular}{cccccccccc}
\hline Attribute & Unit & Mean & Variance & SD & CV & Minimum & Maximum & Skewness & Kurtosis \\
\hline Diameter & $\mathrm{cm}$ & 19.79 & 5.755 & 2.39 & 12.12 & 9.01 & 26.52 & -0.4078 & 1.802 \\
Height & $\mathrm{m}$ & 10.92 & 3.696 & 1.92 & 17.61 & 6.4 & 16.3 & 0.4605 & -0.1389 \\
Condo-10 & $\mathrm{m} \mathrm{dia}^{-1}$ & 97.66 & 4.668 & 68.32 & 69.96 & 7.52 & 330.8 & 0.9706 & 0.5547 \\
Cond $_{10-20}$ & $\mathrm{~m} \mathrm{dia}^{-1}$ & 101.7 & 6.273 & 79.20 & 77.86 & 3.759 & 390.9 & 1.295 & 1.398 \\
$\mathrm{RP}_{0-10}$ & $\mathrm{MPa}$ & 1.183 & 0.1408 & 0.37 & 31.71 & 0.59 & 2.84 & 1.262 & 2.088 \\
$\mathrm{RP}_{10-20}$ & $\mathrm{MPa}$ & 1.988 & 0.9543 & 0.97 & 49.10 & 0.89 & 6.27 & 1.762 & 4.009 \\
$\mathrm{RP}_{20-30}$ & $\mathrm{MPa}$ & 3.764 & 4.612 & 2.14 & 57.05 & 1.11 & 11.55 & 1.488 & 2.12 \\
$\mathrm{RP}_{30-40}$ & $\mathrm{MPa}$ & 4.933 & 4.447 & 2.10 & 42.74 & 1.46 & 12.92 & 1.123 & 1.783 \\
\hline
\end{tabular}

SD: standard deviation; CV: coefficient of variation (\%).

The values of the coefficients of skewness and kurtosis indicate that all data show lognormal distribution of frequency, as these parameters are distanced from 0 to 3, according to CARVALHO et al. (2002). The Figure 2 presents the distribution of frequency histograms for both variables. It appears that even the variables not showing the normal frequency, for most variable the values are close to the average, indicating the average stationary (VIEIRA 2000; SIQUEIRA et al., 2008) or the so-called proportional effect (ISAAKS and SRIVASTAVA, 1989). Thus, the homogeneity of data favors the implementation of the intrinsic hypothesis geostatistics (VIEIRA, 2000) and that the experiment can be repeated even if the samples are collected at different sites because belong to same population sample (SIQUEIRA et al., 2008: SIQUEIRA et al., 2013).
A simple linear correlation (Table 2) shows a medium correlation between the dendrometric characteristics of Hevea brasiliensis (Diameter and Heigth) and the hydraulic conductivity in both studied depths (Cond ${ }_{0-10}$ and Cond ${ }_{10-20}$ ). Furthermore, the values of correlation between the dendrometric characteristics of rubber tree and soil resistance to penetration at different depths ( $\mathrm{RP}_{0-10}, \mathrm{RP}_{10-20}, \mathrm{RP}_{20-30}$ and $\mathrm{RP}_{30-40}$ ) are very low. Among the soil physical attributes (Cond and RP) the coefficient of correlation is very low. Thus, it is important to emphasize that the medium correlation between the parameters of rubber tree and hydraulic conductivity may represent a greater production of natural rubber because greater hydraulic conductivity of the soil in the upper layers results in greater soil water content at more deep soil layers that produces an increment of rubber tree productivity. 

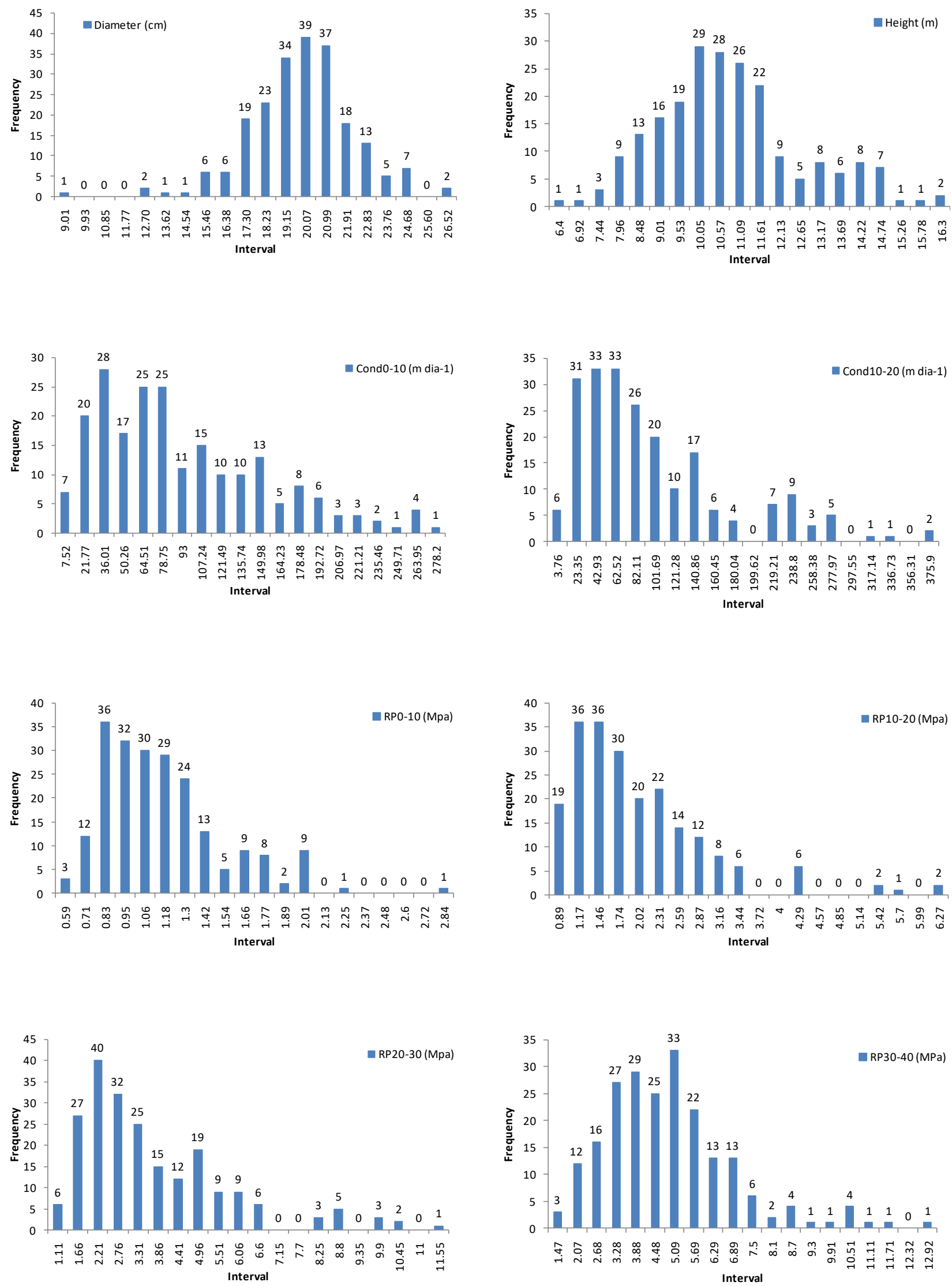

Figure 2. Frequency distribution histogram for the measured variables. 
Table 2. Correlation coefficient among the measured parameters.

\begin{tabular}{|c|c|c|c|c|c|c|c|c|}
\hline & Diameter & Heigth & Cond $0-10$ & Cond $_{10-20}$ & $\mathrm{RP}_{0-10}$ & $\mathrm{RP}_{10-20}$ & $\mathrm{RP}_{20-30}$ & $\mathrm{RP}_{30-40}$ \\
\hline Diameter & 1.000 & & & & & & & \\
\hline Heigth & 0.528 & 1.000 & & & & & & \\
\hline Condo-10 & 0.420 & 0.480 & 1.000 & & & & & \\
\hline Cond $10-20$ & 0.413 & 0.506 & 0.974 & 1.000 & & & & \\
\hline $\mathrm{RP}_{0-10}$ & 0.157 & 0.049 & 0.028 & 0.032 & 1.000 & & & \\
\hline $\mathrm{RP}_{10-20}$ & 0.206 & 0.082 & 0.061 & 0.014 & 0.493 & 1.000 & & \\
\hline $\mathrm{RP}_{20-30}$ & 0.178 & 0.285 & 0.196 & 0.187 & 0.320 & 0.667 & 1.000 & \\
\hline $\mathrm{RP}_{30-40}$ & 0.132 & 0.155 & 0.026 & 0.033 & 0.130 & 0.401 & 0.613 & 1.000 \\
\hline
\end{tabular}

All attributes under study were adjusted to the spherical model, confirming this model as the most fit to the data of soil and plant, as reported by MCBRATNEY and WEBSTER (1986), CAMBARDELLA et al. (1994), SOUZA et al. (2004) and SIQUEIRA et al. (2008) (Table 3 and Figure 3). However, Cond $_{10-20}$ and $\mathrm{RP}_{0-10}$ had pure nugget effect, or the spacing used was not sufficient to detect the spatial variability of these attributes.

The saturated hydraulic conductivity up to $10 \mathrm{~cm}$ deep (Condo-10) showed the highest value of nugget effect $\left(C_{0}\right)$. According VIEIRA (2000) the nugget effect is the discontinuity between samples, or the variability not detected during sampling. This fact is due mainly according to the great variability of the data, as shown by the standard deviation (68.32) and coefficient of variation (69.96\%). The other attributes showed low values of nugget effect.

The dendrometrics parameters of Hevea brasiliensis (diameter and height) had the lowest values of range of the spatial dependence (a), 56.74 and 91.78 meters respectively. The physical attributes of soil water showed higher range values between $150 \mathrm{~m}$ and $234.71 \mathrm{~m}$. The degree of spatial dependence (GD) according CAMBARDELLA et al. (1994) is described as moderate to low among the attributes involved in this study. Since the higher and lower degree of spatial dependence is described to the dendrometrics characteristics of Hevea brasiliensis.

The scaled semivariogram (Figure 4) shows that in general all the variables under study show the same pattern of spatial variability. According to VIEIRA et al. (1983) the scaled semivariogram is an important tool for comparison of the spatial variability of properties with different magnitudes. There is also the height of the trees and soil saturated hydraulic conductivity in the layer of 0.0-0.1 $m$ deep present a slightly different pattern of other variables. Thus, justifying the low values of simple linear correlation between these attributes (Height and Cond $\mathrm{O}_{0}$ ) ) and the other attributes of study.

The map to the diameter of the trees of Hevea brasiliensis this parameter is homogeneous in the study area (Figure 5). When, we compared the maps of tree diameter with height characteristics there are not similar. SANTOS (1982) studied the relationship between characteristics of plants from Hevea brasiliensis and production of natural rubber, found a significant correlation between the diameter of the trees and the production of natural rubber. 
Table 3. Fitted of semivariograma models for the measured variables.

\begin{tabular}{|c|c|c|c|c|c|}
\hline Attribute & Model & $\mathrm{C}_{0}$ & $\mathrm{C}_{1}$ & $a$ & GD \\
\hline Diameter & Spherical & 4.25 & 1.5 & 56.74 & 26.11 \\
\hline Height & Spherical & 1.07 & 2.38 & 91.78 & 69.02 \\
\hline Cond $_{0-10}$ & Spherical & 4300 & 1700 & 150 & 28.33 \\
\hline Cond $_{10-20}$ & \multicolumn{5}{|c|}{ Pure nugget effect } \\
\hline $\mathrm{RP}_{0-10}$ & \multicolumn{5}{|c|}{ Pure nugget effect } \\
\hline $\mathrm{RP}_{10-20}$ & Spherical & 0.73 & 0.33 & 230.47 & 31.08 \\
\hline $\mathrm{RP}_{20-30}$ & Spherical & 2.81 & 2.56 & 234.71 & 47.70 \\
\hline $\mathrm{RP}_{30-40}$ & Spherical & 2.60 & 2.00 & 150.00 & 43.48 \\
\hline
\end{tabular}

Co: efeito pepita; $C_{1}$ : variância estrutural; a: alcance; GD: grau de dependência espacial.
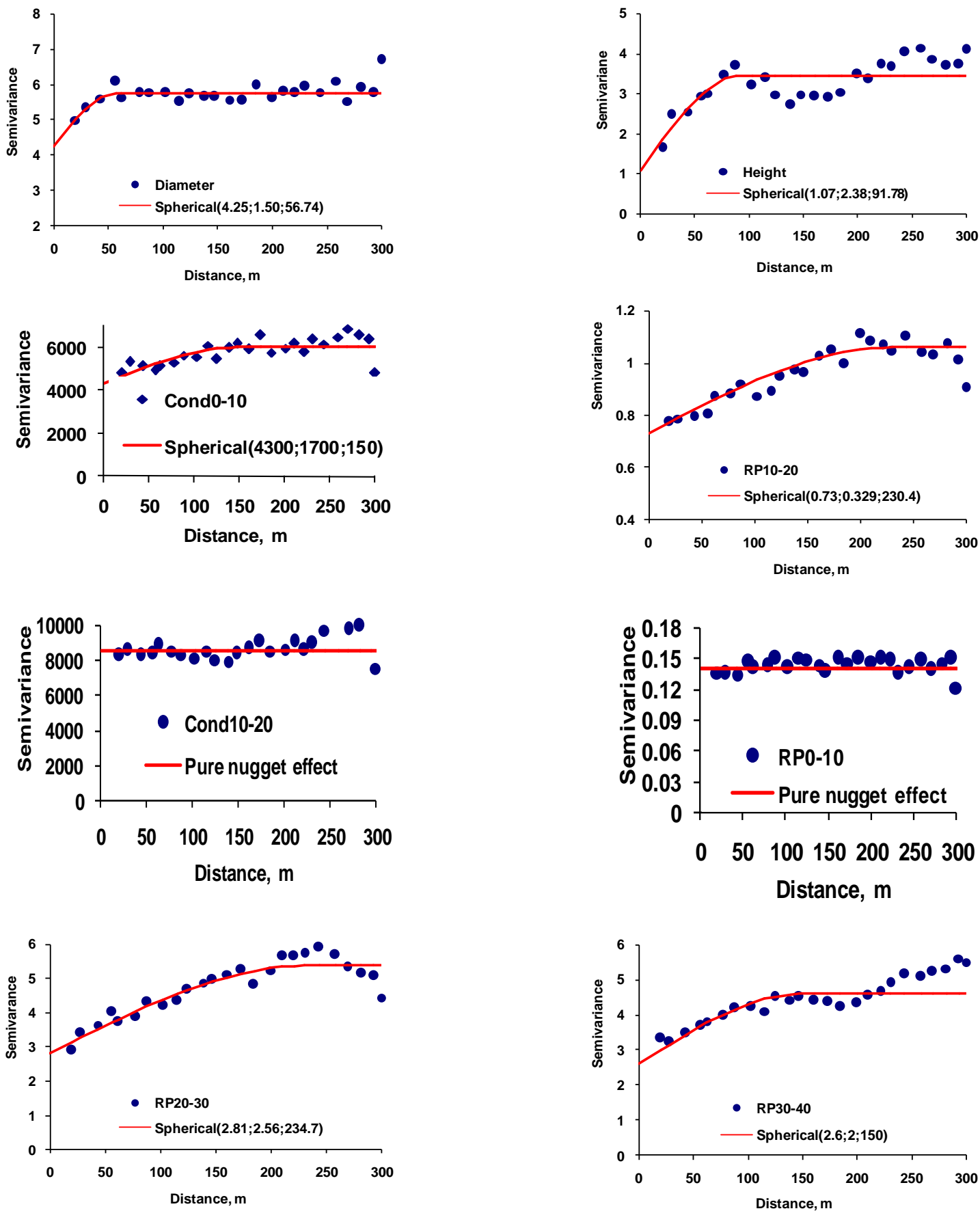

Figure 3. Experimental and fitted model semivariogram of the studied variables sloes. 


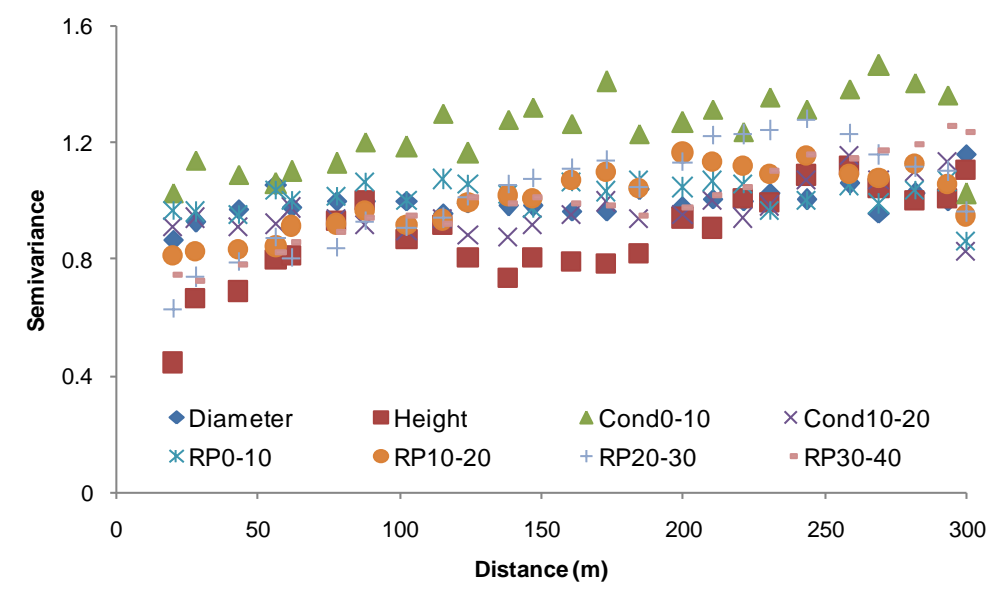

Figure 4. Scaled semivariogram of the studied variables
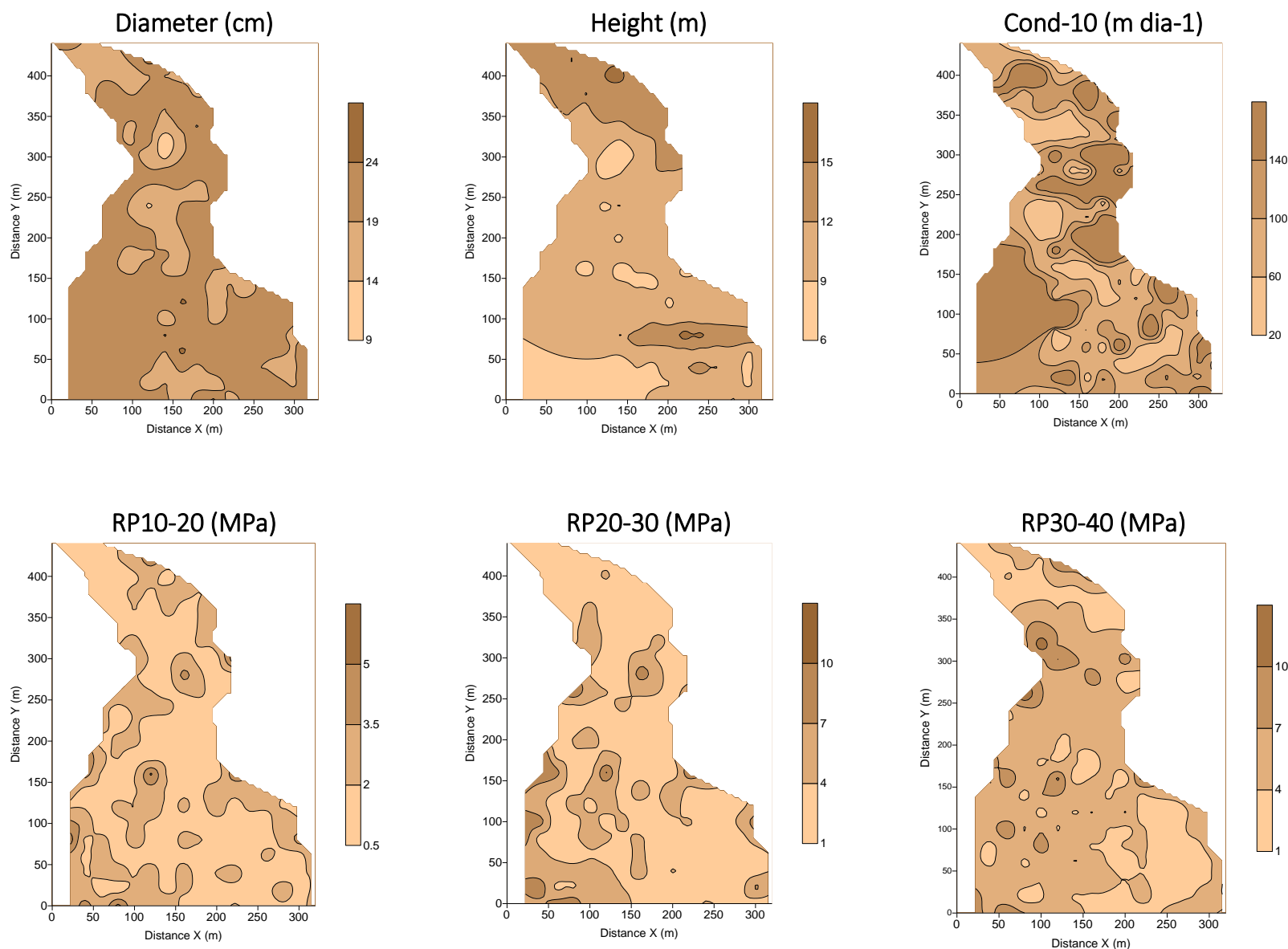

Figure 5. Map of the estimated values obtained by ordinary kriging.

The saturated hydraulic conductivity of the soil up to $10 \mathrm{~cm}$ deep (Condo-10) shows wide variation in the distribution of contour lines. REHFELDT et al. (1992) found high spatial variability of soil saturated hydraulic conductivity of studying a floodplain, whose variability is attributed to factors of soil heterogeneity.

The maps of soil mechanical resistance to penetration confirm the increase in average 
values in depth, as shown in Table 1. See it is also that there is a particular pattern of distribution of contour lines on maps of resistance to penetration. Comparing the maps of soil resistance to penetration with the map of saturated hydraulic conductivity, it appears that areas where there is less hydraulic conductivity or in areas with higher values of soil water content occur smaller values of the resistance to penetration.

According ABRAMS et al. (1992) and MESQUITA et al. (2006) among the many factors that influence the production of natural rubber, the state water of the plant is one that stands out, then, results from the interaction of other factors (evaporative demand of the atmosphere, soil water content, density of planting, cultivation system and physiological processes). In this sense, DEVAKUMAR et al. (1988), describes the dry periods, induce physiological changes in rubber tree which provide a lower productivity. Thus, we emphasize that the presence of areas of spatial variability with lower saturated hydraulic conductivity and lower soil resistance to penetration encouraged the further development of plants from Hevea brasiliensis, as demonstrated by the great uniformity of the diameter of the trees (Figure 5). Thus, resulting in greater production of natural rubber as reported by SANTOS (1982).

\section{CONCLUSION}

The physical attributes of the soil-water showed higher values of coefficient of variation that the dendrometrics characteristics of Hevea brasiliensis. The degree of spatial dependence between samples is low to moderate-all attributes studied. There is a pattern between the maps of spatial variability of the diameter of the trees and saturated hydraulic conductivity, where the areas with high hydraulic conductivity shows highest values of diameter and height. it is possible to use this soil physical property (saturated hydraulic conductivity) as indicator of rubber tree production.

\section{REFERENCES}

Abrams, M.D.; Kloeppel, B.D.; Kubiske, M.E. 1992. Ecophysiological and morphological responses to shade and drought in two contrasting ecotype of Pinnus serotina. Tree Physiology, 10, n.4, p.343-355.

Cambardella, C.A.; Mooman, T.B.; Novak, J.M.; Parkin, T.B.; Karlem, D.L.; Turvo, R.F.; Konopa, A.E. 1994. Field scale variability of soil properties in central lowa soil. Soil Science of America Journal, v.47, p.15011511.

Cardinal, A.B.B; Gonçalves, P.S.; Martins, A.L.M. 2007. Influência de seis porta-enxertos sobre a produção de clones superiores de seringueira. Bragantia, v.66, n.2, p.277-284.

Carvalho, J.R.P.; Silveira, P.M.; Vieira, S.R. 2002. Geoestatística na determinação da variabilidade espacial de características químicas do solo sob diferentes preparos. Pesquisa Agropecuária Brasileira, v.37, n.8, p.1151-1159.

Devakumar, A.S.; Gururaja, Rao G.; Rajagopal, R.; Sanjeeva, Rao P.; George, M.J.; Vijayakumar, K.R.; Sethuraj, M.R. 1988. Studies on soil-plant-atmosphere system in Hevea: II. Seasonal effects on water relations and yield. Indian Journal of Natural Rubber Research, v.1, p.45-60. 
Golden Software Surfer 7.0. 1999. Contouring and 3D surface mapping for scientist's engineers. User's Guide. Golden Software, New York, 1999, 619p

Gonçalves, P.S.; Bataglia, O.C.; Ortolani, A.A.; Fonseca, F.S. 2001. Manual de Heveicultura para o Estado de São Paulo, Instituto Agronômico, Campinas, 2001, 78p

INTERNATIONAL RUBBER STUDY GROUP. 2013. Rubber production statistics,v.5, p.9-10, 2013.

Isaaks, E. H.; Srivastava, R. M. 1989. An introduction to applied geostatistics. New York: Oxford University Press, 1989. 561p.

Kanegae Junior, H.; Mello, J.M.; Scolforo, J.R.S.; Oliveira, A.D. 2007. Avaliação da continuidade espacial de características dendrométricas em diferentes idades de povoamentos clonais de Eucaliptus sp. Revista Árvore, v.31, n.5, p.:859-866.

McBratney, A.B.; Webster, R. 1986. Choosing functions for semivariograms of soil properties and fitting them to sampling estimates. Journal of Soil Science, v.37, p.617639.

Mesquita, A.C.; Oliveira, L.E.M.; Cairo, P.A.R.; Viana, A.A.M. 2006. Sazonalidade da produção e características do látex de clones de seringueira em Lavras, MG. Bragantia, v.65, n.4, p.633-639.

Rehfeldt, K.R.; Boggs, J.M.; Gelhar, L.W. 1992. Field study of dispersion in a heterogeneous aquifer 3. Geostatistics analysis of hydraulic conductivity. Water Resource Research, v.28, n.12, p.3309-3324.

Santos, G.A.; Thomé, C.G. 2007. Prospecção e perspectivas da borracha natural, Hevea brasiliensis. Revista analytica, v.26, p.32-40.

Santos, P.M. 1982. Efeito da interação enxerto $x$ porta-enxerto em seringueira
(Hevea spp.) Ms. Thesis, Universidade de São Paulo.

SOCIEDADE BRASILEIRA DE SILVICULTURA. 2006. Fatos e números do Brasil florestal. SBS, São Paulo, 2006, 106p

Siqueira, G.M.; Silva, E.F.F.E.; Montenegro, A.A.A.; Vidal Vazquez, E.; Paz Ferreiro, J. 2013. Multifractal analysis of vertical profiles of soil penetration resistance at the field scale. Nonlinear Processes in Geophysics, v. 20, p. 529-541.

Siqueira, G.M.; Vieira, S.R.; Ceddia, M.B. 2008. Variabilidade espacial de atributos físicos do solo determinados por métodos diversos. Bragantia, v.67, n.1, p.203-211.

Souza, Z.M.; Marques Júnior, J.; Pereira, G.T. 2004. Variabilidade espacial de atributos do solo em diferentes formas do relevo sob cultivo de cana-de-açúcar. Revista Brasileira de Ciência do Solo, v.28, p.937-944.

Stolf, R.; Fernandes, J.; Furlani Neto, V.L. 1983. Penetrômetro de impacto IAA/PLANALSUCARStolf: recomendação para seu uso. STAB, v.1, n.3, p.18-23.

UNITED STATES DEPARTMENT OF AGRICULTURE. 1996. Keys to soil taxonomy. 7.ed. USDA, Washington, 1996, 644p.

Rosa Filho, G.; Carvalho, M.P.; Montanari, R.; Silva, J.M.; Siqueira, G.M.; Zambianco, E.C. 2011. Variabilidade espacial de propriedades dendrométricas do eucalipto e de atributos físicos de um Latossolo Vermelho. Bragantia, v. 70 , p. $439-446$.

Vieira, S.R. 1998. Permeâmetro: novo aliado na avaliação de manejo do solo. O Agronômico, v.47-50, p. 125.

Vieira, S.R. 2000. Geoestatística em estudos de variabilidade espacial do solo. In: Novais, R.F.; Alvarez, V.H.; Schaefer, G.R. (eds) Tópicos em Ciência do Solo. Sociedade 
Brasileira de Ciência do Solo Viçosa, v.1, p.154.

Vieira, S.R.; Hatfield, J.L.; Nielsen, D.R.; Biggar, J.W. 1983. Geoestatitical theory and application to variability of some agronomical properties. Hilgardia, v.51, n.3, p.1-75.

Vieira, S.R.; Nielsen, D.R.; Biggar, J.W. 1981. Spatial variability of field-measured infiltration rate. Soil Science Society of America Journal, v.45, p.1040-1048.

Warrick, A.W.; Nielsen, D.R. 1980. Spatial variability of soil physical properties in the field. In: Hillel D (ed) Applications of soil physics. Academic Press, New York. 